\title{
An ancient tufa in South Korea associated with topographic evolution from a stable cave environment to a near-surface environment
}

\author{
${ }^{1}$ Division of Geology and Geophysics, Kangwon National University (KNU), 1 Kangwondaehak-gil, Chuncheon-si, Gangwon-do 24341, \\ Republic of Korea; *Corresponding author, E-mail: kjo@kangwon.ac.kr \\ ${ }^{2}$ Critical zone Frontier Research Laboratory (CFRL), Kangwon National University (KNU), 1 Kangwondaehak-gil, Chuncheon-si, Gangwon- \\ do 24341, Republic of Korea
}

(Received: March 24, 2020; Revised accepted: May 1, 2020)

https://doi.org/10.18814/epiiugs/2020/020064

Buried freshwater carbonates in the Moorungri region (Jeongseon-gun, South Korea) were discovered in 2003 during a local excavation for natural ornamental stones. Although the local government recently designated the Moorungri freshwater carbonates (MR-FC) as a potential natural monument based on its surficial beauty, the origin, processes, and depositional environments of the $M R-F C$ are still unknown. This study aimed to determine the origin of the MR-FC based on petrographic and isotopic analyses. On the outcrop scale, the MR-FC overlies typical speleothems (a stalagmite-flowstone sequence) and can be divided into four units (Units 1-4), each of which comprises a pair of carbonate crystalline and clastic beds. Although each clastic bed in the individual units is mainly composed of detrital components, including residual red clays as a weathering product and coarse to medium sand-sized grains from the surrounding carbonate bedrock, several thin layers of authigenic carbonate minerals are observed in the free surfaces and pore spaces of each clastic bed. These features indicate that water supersaturated with calcium carbonate $\left(\mathrm{CaCO}_{3}\right)$ was present throughout the deposition of the MR-FC, although the clastic beds were most affected by episodic pluvial events. Scanning electron microscopy showed that the MR-FC contains not only inorganic components, such as rock fragments and large calcite crystal arrays, but also various biogenic materials such as tree fragments, pollen, spores, fungal filaments, and diatoms. The abundance of biogenic components indicates that the MR-FC was influenced, at least indirectly, by the air outside the cave, and by sunlight. The mean $\delta^{13} \mathrm{C}$ values of the crystalline beds in Units 1, 2, and 4 were $-8.71 \%$, $-8.62 \%$, and $-8.11 \%$, respectively. These values clearly show that the carbonic acid forming $\mathrm{CO}_{2}$ was mostly from meteoric and soil sources. The relationship between the $\delta^{13} \mathrm{C}$ and $\delta^{18} \mathrm{O}$ values in each crystalline bed suggests that the rapid $\mathrm{CO}_{2}$ degassing effect gradually increased relative to the evaporation, implying that the parent water of the upper units in the MR-FC came into abrupt contact with the air outside the cave, which had a lower level of $\mathrm{pCO}_{2}$. This circumstance would arise through cave decay near the discharge location and/or upstream, because removal of the covering bedrock allows for more vigorous degassing of $\mathrm{CO}_{2}$ through numerous openings created by surface denudation. Thus, we concluded that the MR-FC is a tufa deposit that formed during the topographic evolution from a stable cave environment to a near-surface environment.

\section{Introduction}

Freshwater carbonates can be divided into travertine, tufa, and speleothem on the basis of their formation temperature, location and, occasionally, the origin of the contributing $\mathrm{CO}_{2}$ (e.g., Chafetz and Folk, 1984; Ford and Pedley, 1996; Pentecost, 2005). The terms travertine and tufa refer exclusively to hydrothermal and ambient temperature deposits, respectively, as defined by Pedley et al. (2003), while speleothems are limited to secondary mineral deposits in cave environments with permanent dark conditions (Moore, 1952). Calcite, a major mineral component in most freshwater carbonates, precipitates when calcium carbonate $\left(\mathrm{CaCO}_{3}\right)$-saturated groundwater comes into contact with cave air or the outside atmosphere and is then degassed of $\mathrm{CO}_{2}$ (e.g., Kano et al., 2003).

These three types of freshwater carbonates are difficult to distinguish from each other, especially in the case of ancient formations, because they share similar mineralogical and geochemical characteristics, and biogenic components (Evans, 1999; Jones, 2010). Moreover, depositional environments of freshwater carbonates can include two or three gradual facies transitions out of travertine, tufa, and speleothem. For example, travertine deposits commonly evolve into tufa 
facies through gradual lowering of the water temperature and $\mathrm{CO}_{2}$ degassing downstream from the hydrothermal vent (Capezzuoli et al., 2014). In many cases, cave entrance zones clearly show a transition from tufa to speleothems, associated with significant reductions of biogenic components (Taborosi, 2006; Jung and Jo, 2017). Furthermore, tufa is deposited under various open-air environments, such as springs, streams, and lakes (Ford and Pedley, 1996).

Although freshwater carbonates are common in Quaternary deposits, the relative paucity of ancient examples is not understood (Evans, 1999). Several possible reasons proposed by Ford and Pedley (1996) are poor preservation potential, an increasing production rate, and limited freshwater carbonates. Identifying and discriminating among ancient freshwater carbonates is important for understanding the relationship between freshwater carbonates and terrestrial evolution. In an earlier study, it was suggested that facies development of freshwater carbonates mainly depends on the location of carbonate precipitation and, generally, can be controlled by a build-up of phytoherms (Evans, 1999; Lopez et al., 2017). However, no example of differentiation between ancient speleothems and tufa was provided, even though it is expected that tufa can be distinguished from speleothems based on the abundance of various biogenic components.

The Moorungri freshwater carbonates (MR-FC) in Jeongseon-gun, South Korea, were discovered by a local excavation operation for ornamental stone in 2003 (Jo et al., 2007). Although the local government has recently designated the MR-FC as a potential natural monument based on its surficial beauty, the origin, processes, and depositional environments of the MR-FC are still unknown. This study focuses on identifying the origin and depositional processes of the MR-FC based on petrographic and stable isotope data. This study aims to present a new conceptual model of facies transition in ancient freshwater carbonates and the implications thereof.

\section{Geographic Setting}

The climate of Jeongseon-gun, where the MR-FC outcrop is located, is characterized by an annual mean temperature of $10.72^{\circ} \mathrm{C}$ and an annual mean precipitation of $1,048 \mathrm{~mm}$, based on observations made from 2010 to 2019 (Korean Meteorological Administration, 2020). The entire area of the Korean peninsula is a typical East Asian monsoon region with hot, humid summers and cold, dry winters (Fig. 1).

The geological setting of the study area mainly shows early Paleozoic siliciclastic-carbonate succession of the Taebaek Group of the Joseon Supergroup. The Taebaek Group is composed of the Jangsan, Myobong, Daegi, Hwajeol, Dongjeom, Dumugol, Maggol, Jiggunsan, and Duwibong Formations from the Precambrian basement (Yoon, 2007; Chough, 2013). The MR-FC is located on the Daegi Formation, which has been recorded as middle Cambrian shallow marine carbonates (Woo, 2001; Chough, 2013). The MR-FC is also surrounded by the Hwajeol, Dongjeom, Dumugol, and Maggol Formations (all within 1 km; Fig. 1). The Daegi Formation at the MR-FC site consists mainly of massive oolitic limestones, dolomitic limestone, and dolostone (Fig. 2A) (Woo, 2001).

Extensive karst landforms have developed around the outcrop site (Figs. 1 and 2B). More than 12 large dolines with ponors and 10 limestone caves were found from Mt. Mindoong $(1,118.8 \mathrm{~m})$, which is located approximately $500 \mathrm{~m}$ west of the MR-FC outcrop (Woo, 2001). Several karst springs were also observed in the study area. The outcrop exposed near one of the karst springs shows paleokarstic features, such as broken and fossilized speleothems including flowstones and cave coralloids (Figs. 2C and D). Most of the tributary streams around the study area are characterized by dry streams, except in the summer rainy season. The MR-FC is located near the top of a small hillock with no active springs or channels (Figs. 2E and F).

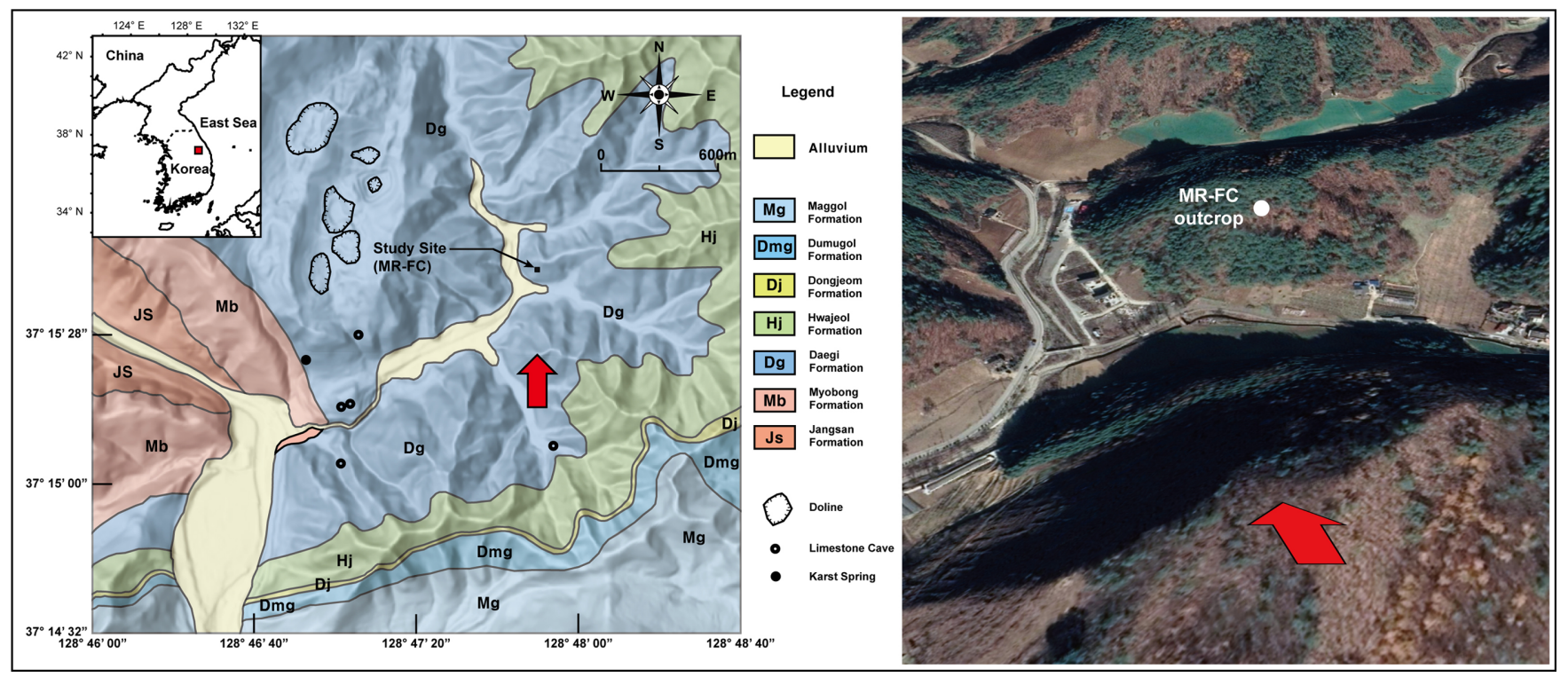

Figure 1. Geologic map of the area surrounding the MR-FC outcrop. A 3D relief map is shown in the left panel. Major karst landforms around the outcrop are also shown. The inset shows the location of Jeongseon-gun on the Korean peninsula (red square). The aerial photograph in the right panel shows the general geomorphology near the outcrop. The large red arrows in both panels indicate the direction from which the aerial photograph was acquired. The base map shown in the aerial photograph and the 3D relief map are from Google Maps. The geologic map is from the Korea Institute of Geoscience and Mineral Resources. 

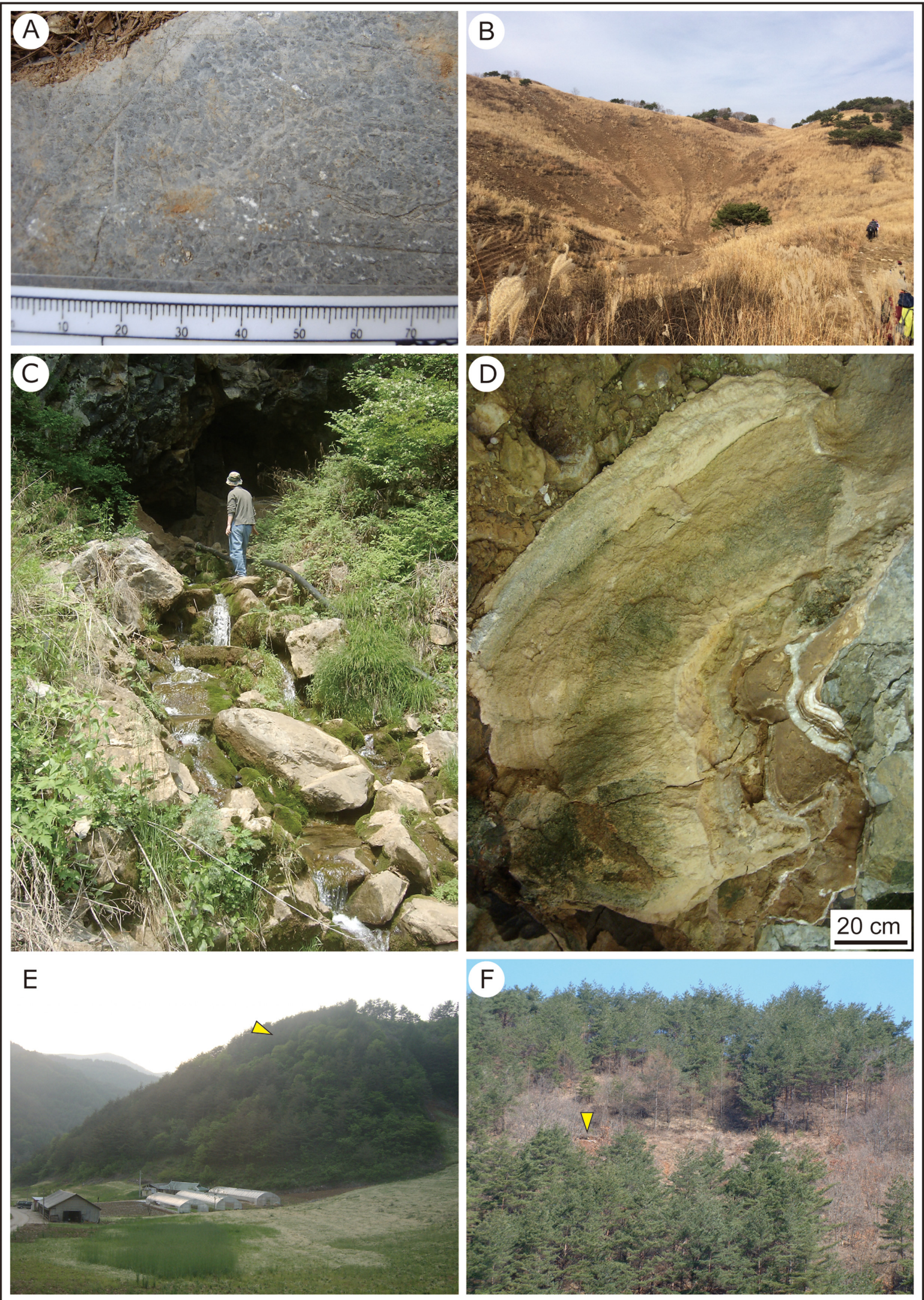

Figure 2. Geological and geomorphic characteristics of the area around the MR-FC outcrop. A) Oolitic limestones serve as representative lithofacies of carbonate bedrock. B) A typical doline in the Mt. Mindoong area. C) A karst spring from the collapsed cave. D) Paleokarstic features near the karst spring. E) A small mountain developed from the MR-FC outcrop. The yellow arrow shows the outcrop position in the hillock (scale, $\sim 10 \mathrm{~m}$ ). F) Panoramic photograph of the MR-FC outcrop. The yellow arrow indicates the exact position of the outcrop (scale, $\sim 3 \mathrm{~m})$. 


\section{Materials and Methods}

Most of the MR-FC was buried under the soil at the time of its initial discovery by the local people. After the excavation, the thickness of the MR-FC was measured throughout the entire section of the uncovered outcrop using a portable cutting machine (Figs. 3A-F). All of the rock samples were halved and polished in the laboratory. Thin sections and acetate peels were made using one side of each sample, and stained with Feigl's and Alizarin Red S solutions. The thin sections were observed under binocular (SMZ800; Nikon, Tokyo, Japan) and polarized (Eclipse LV100; Nikon) microscopes.

For scanning electron microscopy (SEM), subsamples of microgram-sized particles were prepared using a mechanical press and $\mathrm{Na}_{2}$ $\mathrm{SO}_{4}$ solution. All SEM images reported in this study were acquired by a secondary electron detector with an accelerated voltage of $20 \mathrm{kV}$

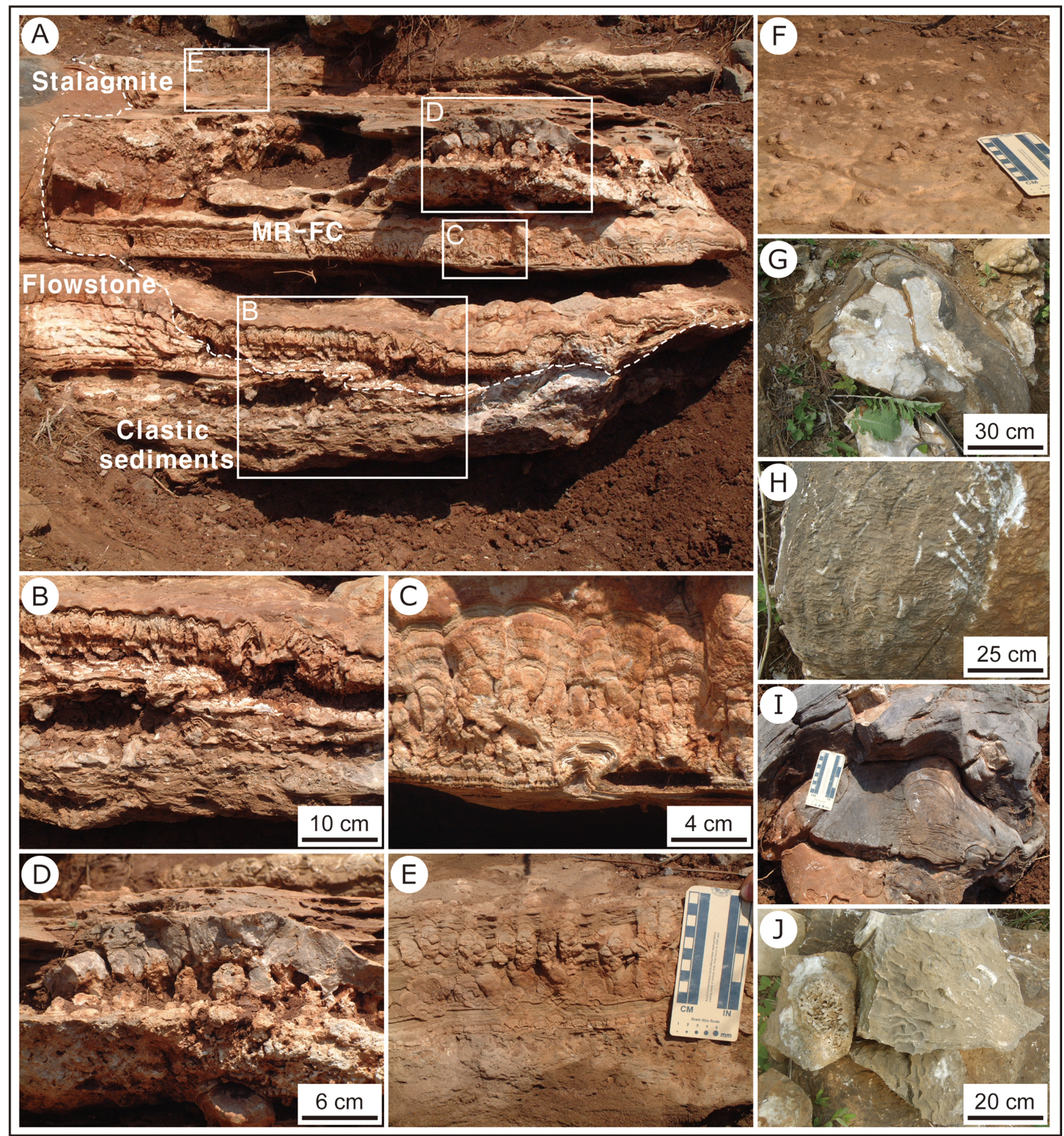

Figure 3. The major section of the MR-FC and fossilized speleothems located nearby. A) Overview of the MR-FC. A speleothem sequence (from stalagmite to flowstone) is shown on the left-hand side. The rectangles indicate close-up views. The dashed line indicates the boundary between the MR-FC and cave sediments (cave clastic deposits and speleothems). B) Close-up view of Unit 1. C) Unit 2. D) Unit 3. E) Unit 4. F) Calcite aggregates in Unit 4. G) A typical stalagmite underlying the MR-FC. H) A fossilized flowstone on the left side of the MR-FC. I) A block of fossilized flowstone. J) Other broken speleothems, including rimstones and an anthodite. 


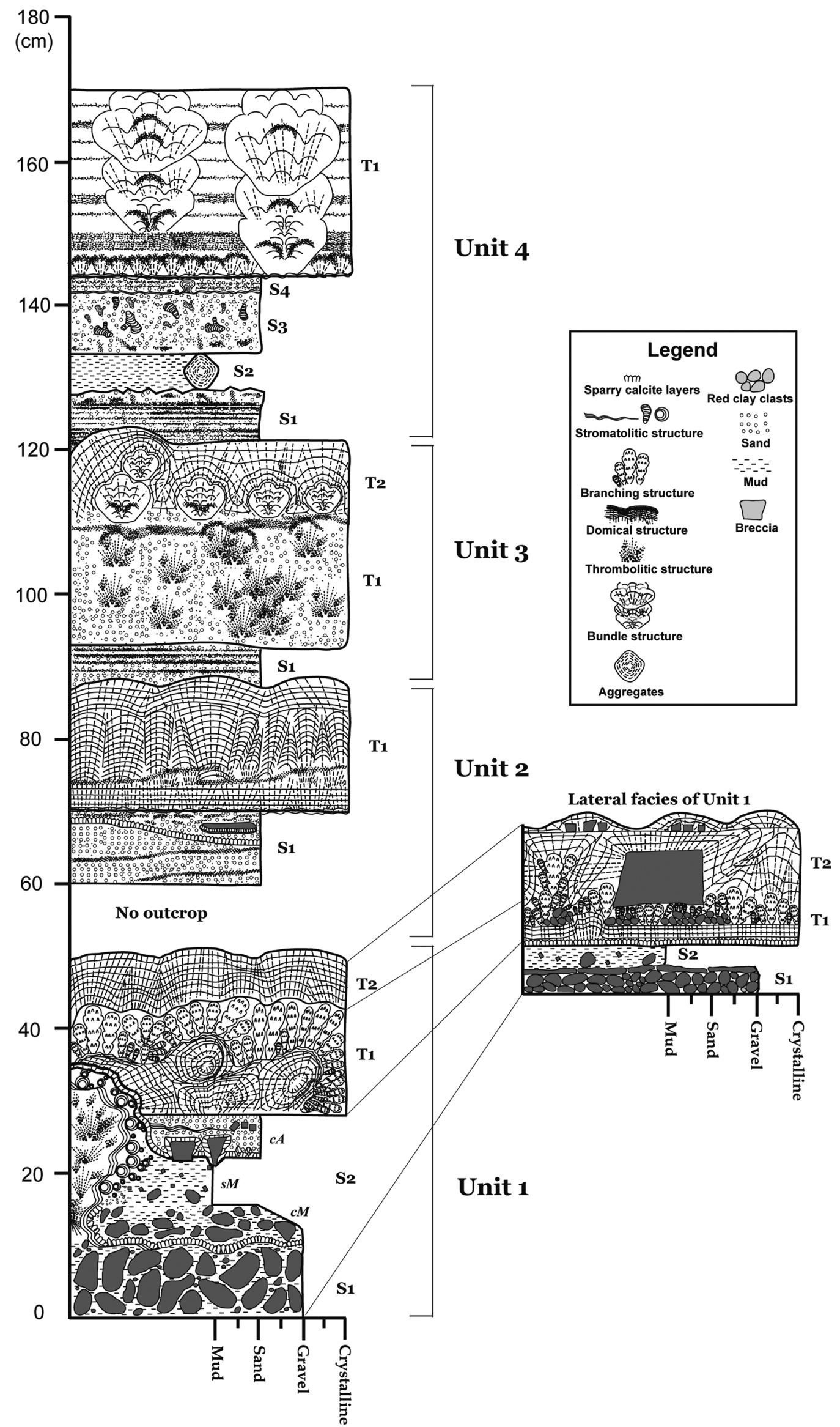

Figure 4. A columnar section of the MR-FC (modified from Jo et al., 2007). 
and working distance of 7-15 mm. Each subsample was coated with $\mathrm{Au}$ in an ion sputter (SPT-20; COXEM, Daejeon, South Korea) and then observed by a low-vacuum SEM instrument (S-3500N; Hitachi, Tokyo, Japan) belonging to the Korean Basic Science Institute (KBSI) and housed at Kangwon National University. Energy-dispersive X-ray spectroscopy (EMAX; Horiba, Kyoto, Japan) was used for qualitative chemical analyses of the subsamples during SEM imaging.

Carbon and oxygen isotope analyses were carried out using an isotope ratio mass spectrometer (Prism; VG Isotech, Middlewich, UK) belonging to the KBSI. All of the stable isotope data reported herein are expressed as $\delta$ (per mil, \%o) relative to the Vienna Pee Dee Belem-

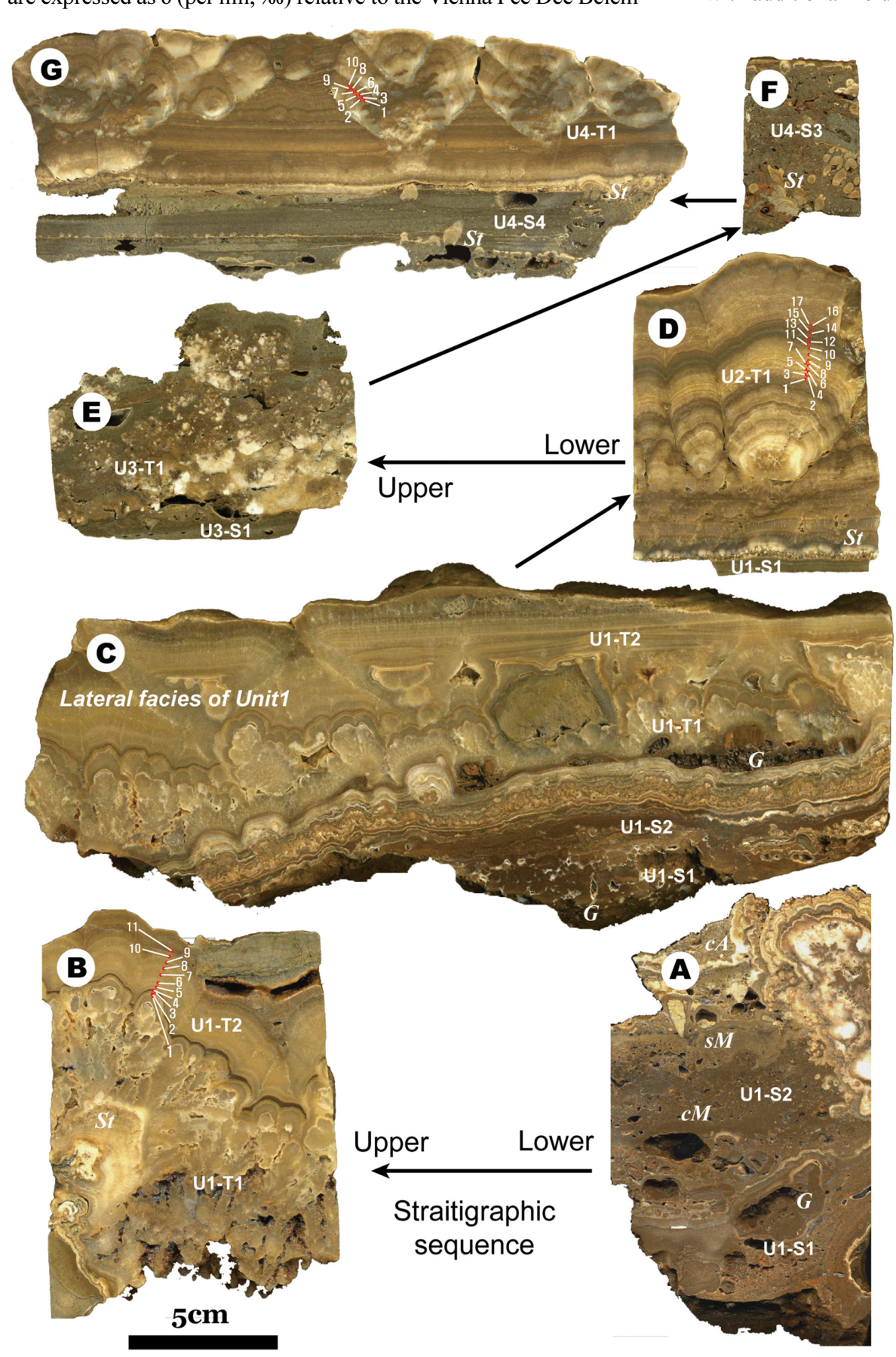

Figure 5. Photographs of rock slabs from the MR-FC. A-C) Unit 1. D) Unit 2. E) Unit 3. F-G) Unit 4. Note that the subsampling points for $\delta^{13} C$ and $\delta^{18} O$ analyses are indicated in $\left.\left.B\right), D\right)$, and G) for Units 1, 2, and 4, respectively (modified from Jo et al., 2007). nite standard. The analytical error for carbon and oxygen isotopes is \pm $0.08 \%$ and $\pm 0.10 \%$, respectively.

\section{Results}

\section{Outcrop-scale Lithofacies}

Outcrop-scale petrographic data were previously reported by Jo et al. (2007). In this study, those data were reinterpreted in combination with additional field and laboratory observations. A typical section of the MR-FC shows a thickness of $1.7 \mathrm{~m}$ (Fig. 3A). Additional excavations of the outcrop were performed and the MR-FC was found to extend at least $10 \mathrm{~m}$ from the main outcrop. A significantly weathered stalagmite is located on the left side of the main outcrop, and various typical speleothems, including flowstone, rimstone, and even anthodites, were excavated as broken pieces at approximately $9 \mathrm{~m}$ from the main outcrop (Figs. 3G-J). In general, the MR-FC exhibits regular alternations of carbonate crystalline and clastic beds, and can be divided into four units (Units 1-4; one for each pair of beds) (Fig. 4). The typical speleothems indicate that a stable cave environment preceded the deposition of the MR-FC (Figs. 3A and G). The central lower part of the main outcrop shows a concave shape, like the cross section of a channel (Fig. 3A).

The clastic bed of Unit 1 can be subdivided into four layers (Unit 1-S1 to Unit 1-S2-cA) (Figs. 4 and $5 \mathrm{~A}$ ). This bed is composed mainly of fine pebble-sized $(0.5-4 \mathrm{~cm})$, semi-consolidated clasts and red-colored muddy silt and clay, with several thin bands of sparry calcites (Fig. 5A). Well laminated red-clay and rockfall deposits underlie the semi-consolidated clasts. Irregular thrombolite and micro-stromatolite-like structures are abundant, and irregular pore spaces were filled with thin aragonite cements $\sim 0.2-\mathrm{mm}$ in thickness (Figs. 6A and B). Very angular pebblesized breccia and sand-sized dolomite fragments are sparsely present (Figs. 5B and C). The crystalline bed of Unit 1 consists mainly of welldeveloped branching and domical structures of large sparry calcite (Fig. 5B). In the lateral facies of the main outcrop, there are domical structures with flat surfaces (Fig. 5C).

The clastic bed of Unit 2 was mostly eroded, but some parts are characterized by medium sand composed mainly of dolomite fragments with low roundness. Sedimentary structures on the rock slab exhibit cross-bedding and bioturbation (Figs. 6C and D). A 2-mm-thick band of sparry calcites with gentle inclination is embedded in the clastic bed. Micro-stromatolitic structures 
are present in the bottommost part in the crystalline bed of Unit 2 (Figs. 5D and 6E). This band displays a very thin and flattened bedding plane, unlike the channel-like concave plane in Unit 1. The domical structure predominantly comprises large fan-shaped crystalline calcite arrays (Figs. 5D and 6E). The crystalline bed of Unit 2 shows numerous growth laminae with impurity-rich bands.

Unit 3 mostly shows typical thrombolitic structures within its clastic bed, while the lowermost parts of the bed show a relatively welllaminated detrital layer (Fig. 5E). The white-colored thrombolitic "clumps" show a highly sporadic occurrence and large pores, and exhibit

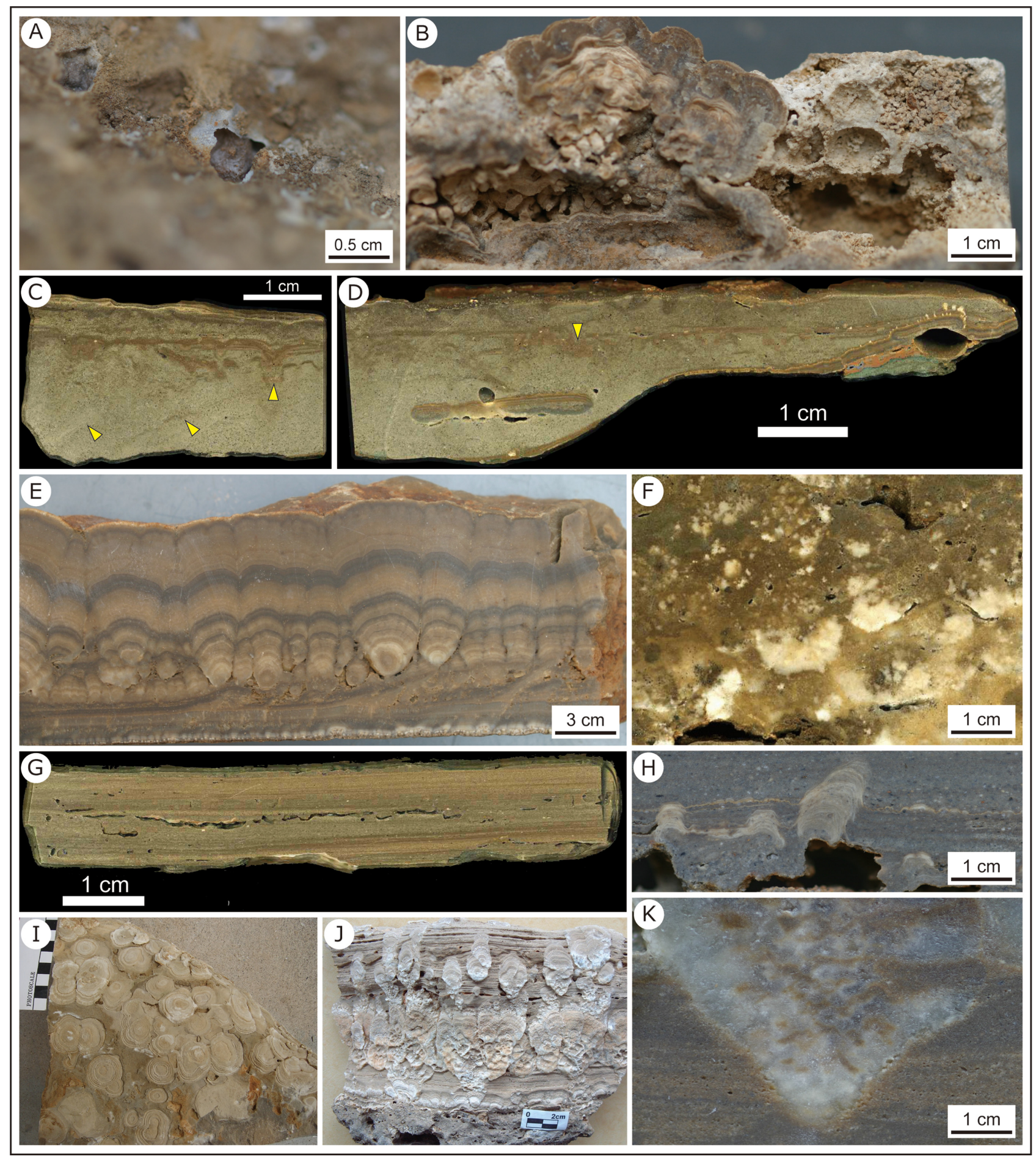

Figure 6. Petrographic features on rock slabs from the MR-FC. A) The aragonite cements observed in the pore spaces in the clastic bed of Unit 1. B) Micro-stromatolitic structures with irregular pores. C) The clastic bed of Unit 2. Yellow arrows on the left and in the middle indicate cross-bedding. The yellow arrow on the right shows the bioturbation. D) View of C) from the right-hand side. The yellow arrow indicates bioturbation. E) The crystalline bed of Unit 2. F) The thrombolitic structure of Unit 3. G-H) Well-laminated clastic beds of Unit 4 showing irregular pores and micro-stromatolitic structures. I-K) Crystalline beds of Unit 4 from various viewpoints. Note that bundle structure growth is initiated after deposition. 
the characteristics of post-depositional alteration rather than a syndepositional structure (Fig. 6F). The clastic sediments are composed of dark grey-colored muddy sand. The crystalline bed of Unit 3 shows weak development relative to those of the other units, and the calcite arrays can be subdivided into bundle and domical structures.

The clastic bed of Unit 4 consists mainly of medium sand grains (Fig. 6G) and is characterized by self-regulating micro-stromatolitic structures appearing as several bands (Figs. 5F-G and 6H). Also, granule-sized carbonate fragments originating from the micro-stromatolitic structures are commonly embedded in the clastic bed, and show extremely fine internal laminations on the rock slab (Figs. 5F and 6H). The crystalline bed of this unit predominantly shows bundle structures occurring in well-laminated sediment-rich layers (Figs. 5G and 6I-K).

\section{Microscopic Examinations}

Microscopic analyses indicated that the MR-FC includes 1) detrital components with calcium carbonate cement in its pore spaces, 2) chemical precipitates from free surfaces, and 3) biogenic components (Figs.
7-9), in line with previous microscopic results (Jo et al., 2007). The semi-consolidated clasts in the clastic bed of Unit 1 show brittle features (Fig. 7A). The outer surface of each clast is cemented by spherulitic fibrous to acicular aragonites (Fig. 7B), and the cements include a few laminae with high impurity content, indicating that the supply of detritus was intermittent even during the precipitation of cements. The clastic beds of all units include many organic fragments (Fig. 7C). In the crystalline bed of Unit 1, a dark clotted texture is observed (Figs. $8 \mathrm{~A}-\mathrm{C}$ ). Clean well-developed calcites, which appear as branching structures in the crystalline bed of Unit 1 , can be easily distinguished from the outer crystal layer with the clotted texture. The area showing a clotted texture was surrounded by equant calcite having both small and large crystals. Some layers in Units 1-4 include pisoid- and ooidlike coated grains with nuclei of dolomitic rock fragments (Figs. 7D and E). The area with a clotted texture in Unit 3 is of the most intense among all units of the MR-FC, and shows large and irregular pore spaces (Figs. 8D-F). The crystalline beds of Units 3 and 4 have large bundle structures, originating from small pore spaces that allowed them to accept large amounts of pore water (Fig. 7F). The pore spaces are also related to the initially intergranular pores between granule-
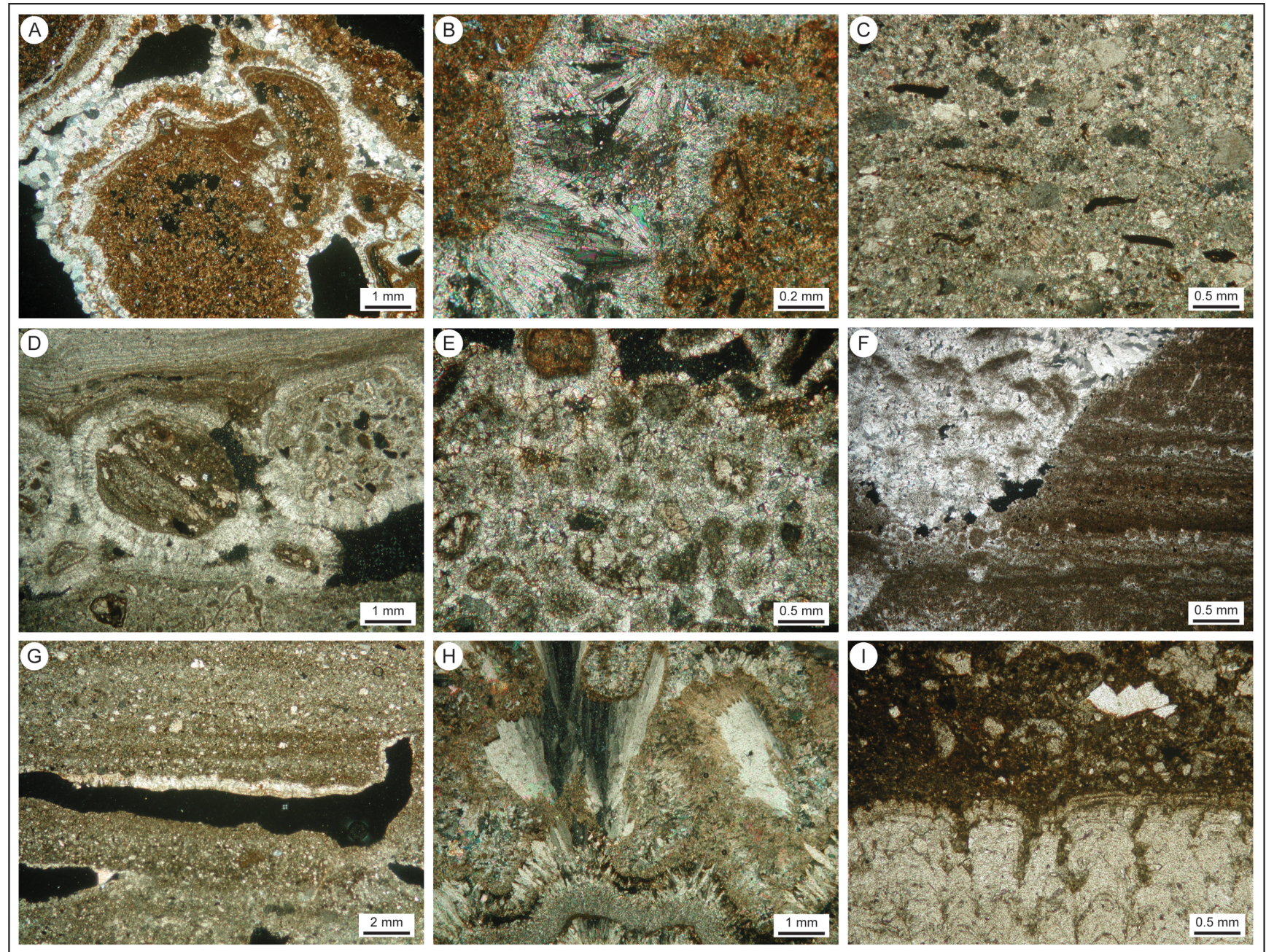

Figure 7. Photomicrographs of inorganic depositional components from the MR-FC. A) Semi-consolidated red clay clasts and calcium carbonate cements. B) Aragonite cements in intergranular pores between red clay clasts. $C)$ Poorly sorted rock fragments from dolomite bedrock. Black organic matter is abundant. D) Pisoids. E) Ooids. F) The lowermost part of a bundle structure. G) Stalactitic cements. H) Extensively corroded features in the crystal arrays. I) Corroded outmost surface of the crystalline bed. 

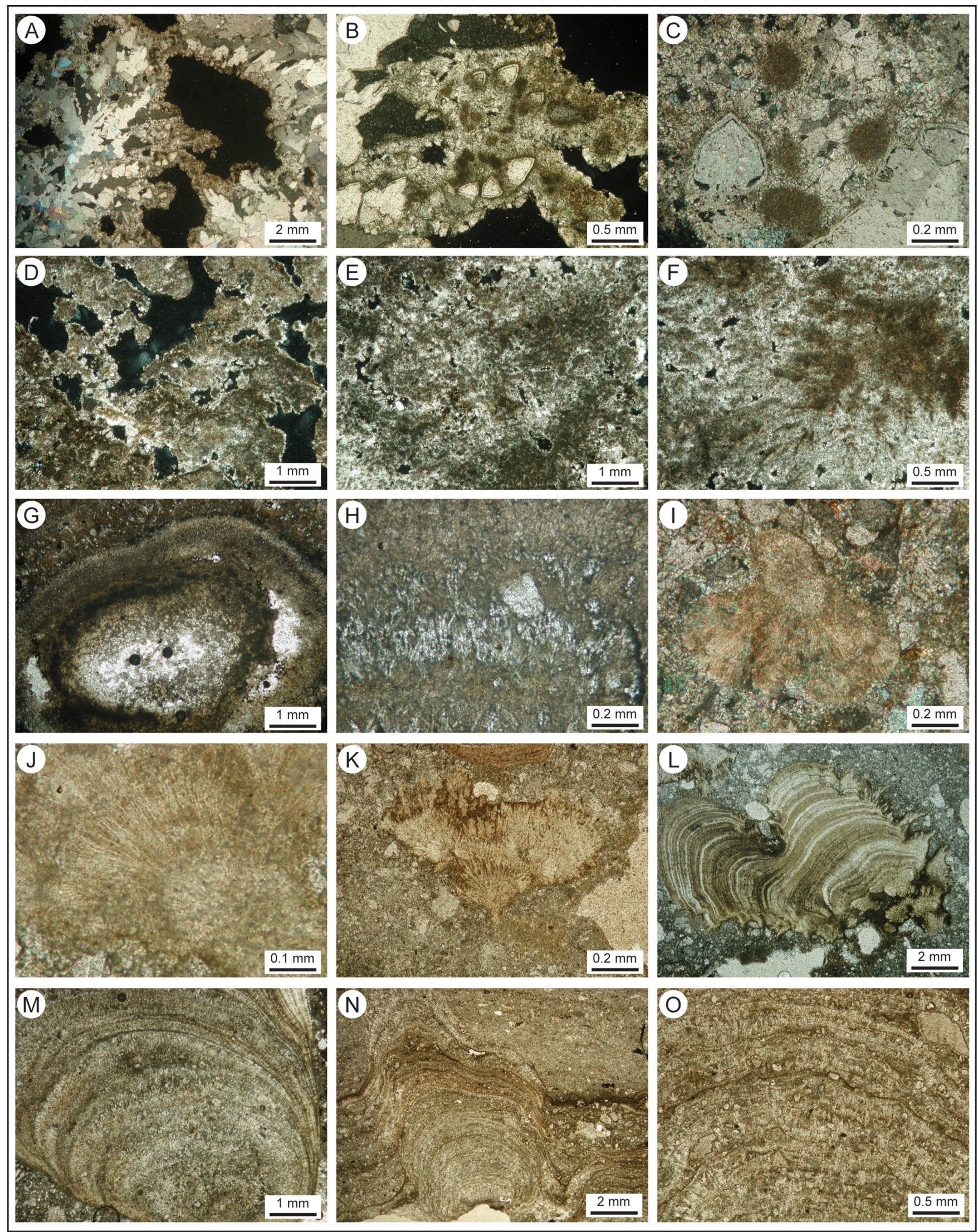

Figure 8. Photomicrographs of biogenic textures from the MR-FC. A-C) Clotted texture on the outmost part of the branching structure in Unit 1. D-F) Clotted texture dominates the thrombolitic structure of Unit 3. G) Core of the micro-stromatolitic structure. H) Filamentous textures from the outer part of $G$ ). I-K) Clumps of filaments from micro-stromatolitic fragments. L-M) Micro-stromatolitic fragments in the clastic bed of Unit 4. N) A micro-stromatolitic structure in the clastic bed of Unit 4. O) A close up view of N). 
and coarse sand-sized aggregated grains. The carbonate fragments in Unit 4 with micro-stromatolitic structures show various types of dominant filamentous textures (Figs. 8G-M). Furthermore, the self-regulating micro-stromatolitic structures are characterized by filamentous textures and show binding of detrital grains (Figs. 8N and O). Meteoric cements and corroded surfaces from various carbonate crystals are abundant in all four units (Figs. 7G-I).

SEM analysis shows that Unit 1 has euhedral fibrous aragonite crystals grown from the outer surfaces of semi-consolidated red clay clasts (Fig. 9A). The calcite-coated grains are surrounded by columnar crystals grown from the surface of a detrital nucleus (Fig. 9B). Auto-micritic cements composed of equant calcite are abundant throughout the MRFC (Fig. 9C). Unlike the euhedral aragonites and calcites with clean crystal faces, the areas showing a clotted and filamentous texture, along with carbonate components, exhibit extremely irregular and anhedral crystals with possibly fungal filaments (Fig. 9D). The micro-stromatolitic structures consist of relatively thick columnar calcite bands, filaments, and coccoid-shaped particles entangled with a type of mucus material (Figs. 9E and F). Diatom colonies were identified above the clastic bed of Unit 1, and were mainly attached to fossilized tree fragments (Figs. 9G-I). Pollen grains and various filaments are commonly observed throughout the MR-FC (Figs. 9J-L).

\section{Stable Isotope Results}

In this study, stable isotope analyses were carried out of the crystalline beds of Units 1, 2, and 4, which show regular growth laminations (Figs. 5 and 10). The carbon and oxygen isotope compositions of Unit
1 range from $-9.88 \%$ o to $-8.03 \%$ and $-9.39 \%$ o to $-8.49 \%$, respectively. The $\delta^{13} \mathrm{C}$ and $\delta^{18} \mathrm{O}$ values of Unit 2 range from $-9.60 \%$ to $-7.94 \%$ and -9.58 to $-8.19 \%$, respectively. In Unit 4 , the $\delta^{13} \mathrm{C}$ and $\delta^{18} \mathrm{O}$ values range from $-9.71 \%$ to $-6.30 \%$ and $-9.33 \%$ to $-8.83 \%$, respectively. The mean $\delta^{13} \mathrm{C}$ values for Units 1,2 , and 4 are $-8.71 \%$, $-8.62 \%$, and $-8.11 \%$, respectively, and those of $\delta^{18} \mathrm{O}$ are $-8.71 \%$, $-8.62 \%$, and $-8.11 \%$, respectively. Clear correlations in carbon and oxygen isotope values can be seen in all units, with $\mathrm{R}^{2}$ values of $0.53,0.55$ and 0.54 for Units 1, 2, and 4, respectively (Fig. 10). Units 1 and 2 show very similar isotopic characteristics in terms of the ranges of both carbon and oxygen isotopes. Carbon and oxygen isotope excursions in Unit 1 can be observed in the middle part of the sampling location, indicating that the black laminae are not directly related to the excursions of either isotope. While the range of $\delta^{13} \mathrm{C}$ values for Unit 4 is clearly wider compared to those for the other units, the $\delta^{18} \mathrm{O}$ values for Unit 4 show a much narrower range compared to those for the other units. Unit 4 shows a very constant oxygen isotope value, but a wide range of carbon isotope values.

\section{Discussion}

\section{Interpretation of Petrographic and Stable Isotope Data}

Based on the petrographic data generated by both outcrop observations and microscopic examinations, most of the clastic bed in Unit 1 is comprised of cave clastic sediments deposited in a small cave channel or pond-like micro-geomorphological feature (Fig. 3A). This is strongly

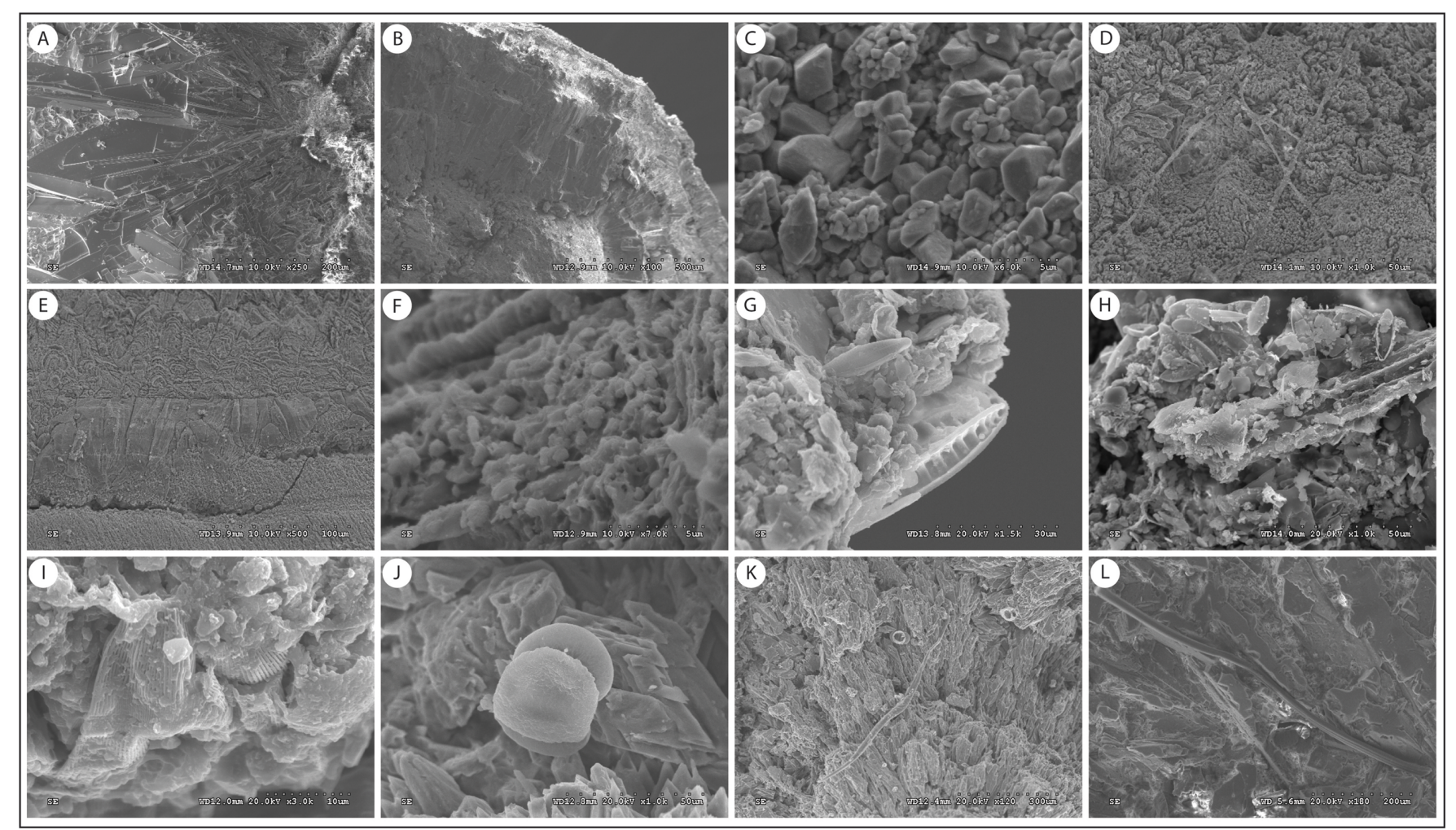

Figure 9. SEM photomicrographs of the MR-FC. A) Aragonite cements in intergranular pores between red clay clasts. B) Calcite cortex of a pisoid grain. C) Calcite cements in the pore spaces of the crystalline bed in Unit 1. D) Fungal filaments attached to anhedral crystals. E) Fine laminations in micro-stromatolitic structures. F) Close-up view of E). G-I) Colonies of diatoms. J-L) Pollen grains and fungal filaments. 

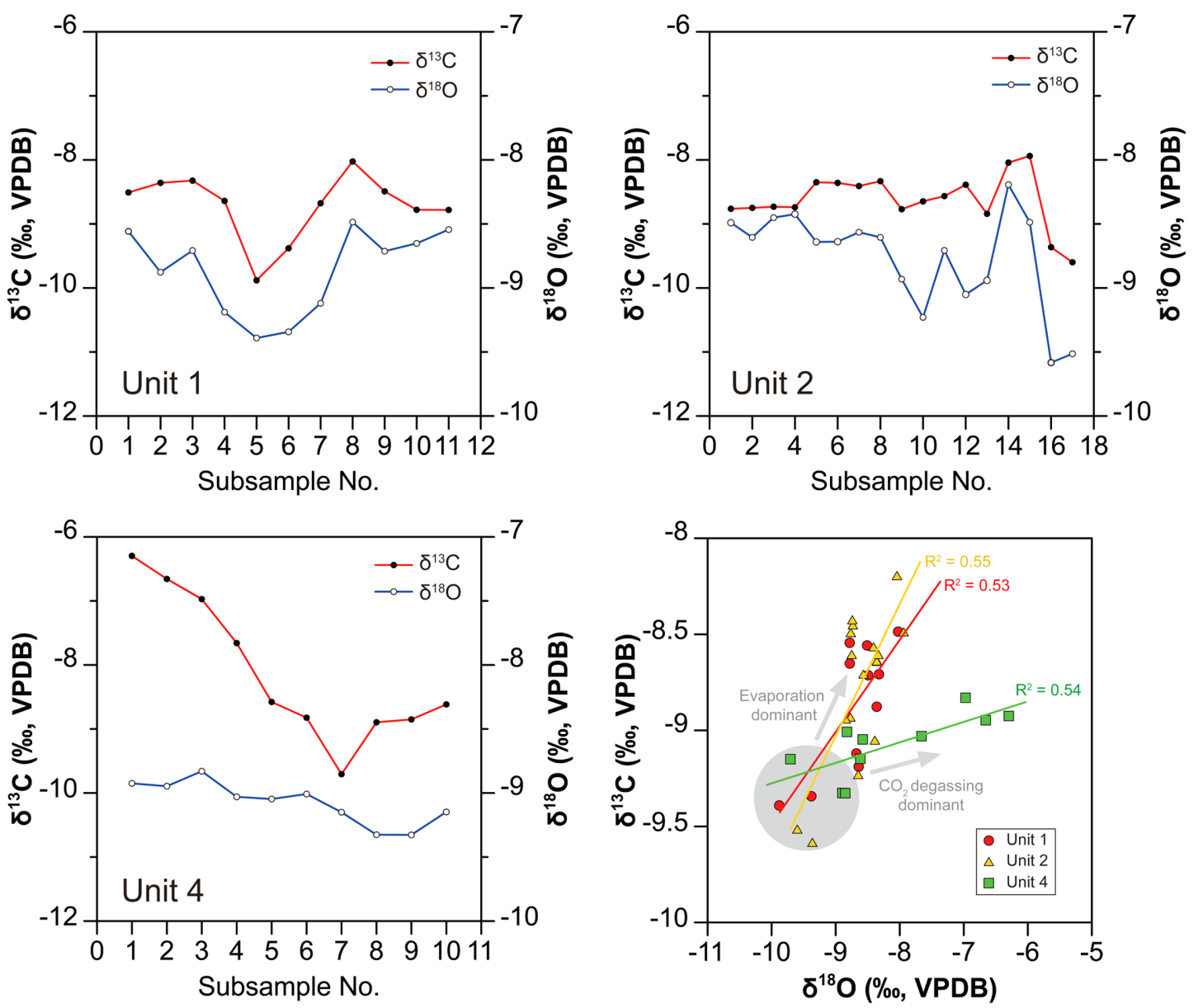

Figure 10. Stable isotope profiles of $\delta^{13} \mathrm{C}$ and $\delta^{18} \mathrm{O}$ for Units 1, 2, and 4. A) Unit 1. B) Unit 2. C) Unit 4. Note that the y-axes for all profiles are unity. D) Scatter plot of $\delta^{13} C$ and $\delta^{18} O$ values for Units 1, 2, and 4. The gray circle indicates the inferred range of isotope values for the recharge waters. Units 1 and 2 were affected by evaporation, while Unit 4 was mainly controlled by rapid $\mathrm{CO}_{2}$ degassing.

supported by the presence of typical stalagmites and other various types of speleothems (Hill and Forti, 1997) (Figs. 3G-J). The concave bedding plane of Unit 1 and the clastic bed of Unit 2 suggest that a weak channel or small pond was present before the deposition of the MR-FC. The laminated deposits of red clay in the clastic bed of Unit 1 suggest chemical weathering of the soil zone upstream and relatively calm subaqueous conditions (Knapp et al., 2007) (Fig. 11A). However, intermittent flooding likely produced the semi-consolidated red clay clasts and redeposited them immediately in front of the crystalline bed of Unit 1 (Figs. 5A and 11A). The pebble-sized breccias throughout Unit 1 indicate the existence of a cave roof or steep wall near the MRFC, given its highly angular grain shape characteristic of deposition by gravity (Bosch and White, 2007) (Figs. 5B and C). No breccias were observed above Unit 1, indicating that any previous source thereof may have been removed after the deposition of Unit 1. Also, there are no red clay deposits above Unit 1, indicating that the ratio of physical fragmentation to chemical weathering was altered between the clastic beds of Units 1 and 2 (Fig. 5).

The thin crystal bands and intergranular cements of euhedral acicular aragonite and equant calcite in the MR-FC indicate large differences in the saturation states of calcium carbonates of the parent water (González et al., 1992) (Fig. 7). The carbonate-coated grains and various corrosion features also indicate large changes in saturation states and flow rates.
The clastic beds of Units 2-4 are composed mainly of dolomite fragments with very poor sorting and low roundness, suggesting that the flow velocity of water changed rapidly (Bosch and White, 2007) (Figs. $7 \mathrm{C}$ and $\mathrm{G}$ ). The higher content of organic fragments (sedimentary grains) above the clastic beds in Unit 2 implies that the depositional conditions changed from oligotrophic to eutrophic (Jung and Jo, 2017). Irregular vuggy pores are likely to represent the residue of decayed organic particles (Fig. 7G). The crystalline beds of Units 3 and 4 are characterized by well-developed bundle structures within laminated sediment-rich layers. This feature indicates that the initially crystalline bundles gradually built up inside of sediments with a shallow depth (Fig. 7F). After deposition of the clastic bed in Unit 1, significant supersaturation of water with calcium carbonate occurred for the first time in the MR-FC (e.g., González et al., 1992), after which the saturation states and water flow rates became highly variable with the inputs of organic particles during the crystalline bundle build-up phase. The microbial textures, including filamentous and micritic clotted textures, appear at the boundary between the clastic and crystalline beds in Unit 1. In particular, the microbial textures are predominant in the micro-stromatolitic and thrombolitic structures of Units 3 and 4. The thrombolitic structures of Unit 3 appear as typical microbial structures, given the endolithic activities observed in subsurface environments associated with the highly predominant micritic clumps and filamentous 
textures (Jones, 2010). On the other hand, the self-regulated microstromatolitic structures and fragments suggest epilithic products, based on the arrangements of the filaments from the former substrates (Jones, 2010). These microscopic observations were confirmed by SEM, which revealed fungal filaments, diatoms, pollens, spores, and tree fragments (Jo et al., 2007) (Fig. 9). This assemblage of microscopic biogenic components is very similar to those of the tufa deposit recently discovered at the entrance to the twilight zone of Baeg-nyong Cave, South Korea (Jung and Jo, 2017). The MR-FC contains various biogenic components with photosynthetic organisms, which eventually would have been affected by sunlight, at least indirectly, in a location close to the surface (Taborosi, 2006). This is supported by parts of the MR-FC showing a clear transition from typical stalactites to micro-stromatolitic structures (Figs. 11B and C).

Jo et al. (2007) reported that the MR-FC formed during Marine Isotope Stage 5e. However, ${ }^{230} \mathrm{Th} /{ }^{234} \mathrm{U}$ dating implied a much earlier formation time (at least $>400 \mathrm{ka}$ ), although there is large uncertainty (unpublished data). Stable isotope data of the MR-FC fell into the ranges of typical speleothems in South Korea and normal tufa reported from temperate regions (Andrews, 2006) (Fig. 10). Even slight involvement of thermal waters can enhance ${ }^{13} \mathrm{C}$ in limestone bedrock, due to longer and deeper circulation (e.g., Arenas et al., 2000), and the isotopic data confirm that the MR-FC is not a travertine formed by thermal spring water. The $\delta^{13} \mathrm{C}$ and $\delta^{18} \mathrm{O}$ values for Unit 4 are distinct from those for Units 1 and 2, indicating that different physicochemical processes occurred in the parent water of the MR-FC (Andrews, 2006).

The $\delta^{18} \mathrm{O}$ content of tufa and speleothems is influenced by water isotope composition and temperature (e.g., Andrews, 2006; White, 2007). The kinetic processes involved in isotope fractionation, such as evaporation, can also affect the $\delta^{18} \mathrm{O}$ content of freshwater carbonates (White, 2007). Although all of these factors could influence the ${ }^{18} \mathrm{O}$ values for Unit 4, it is well known that the main factor controlling the $\delta^{18} \mathrm{O}$ content of tufas and speleothems is the oxygen isotope composition of the recharge water from local precipitation (Andrews, 2006; Jo et al., 2010). Meanwhile, the $\delta^{13} \mathrm{C}$ content of tufas and speleothems is influenced by vegetation type, terrestrial productivity, degassing processes, and water-soil-rock interactions, etc. (Jo et al., 2010). The carbon isotope compositions of all units of the MR-FC show $\delta^{13} \mathrm{C}$ values within the ranges of Korean speleothems, which have been posited to denote the magnitude of terrestrial productivity along with various other factors (Jo et al., 2010).

The most notable characteristic of the carbon and oxygen isotope data from the MR-FC is the strong correlation between the $\delta^{13} \mathrm{C}$ and $\delta^{18} \mathrm{O}$ values for all units (Fig. 10). This suggests a strong influence of kinetic fractionation on stable isotope values in the MR-FC, where disequilibrium processes such as rapid $\mathrm{CO}_{2}$ degassing will promote more positive ${ }^{13} \mathrm{C}$ and $\delta^{18} \mathrm{O}$ values during tufa deposition (Usdowski et al., 1979; Dandurand et al., 1982) and speleothem deposition (Hendy, 1971). As the carbon isotope fractionation occurring during calcite precipitation is insensitive to temperature (Romanek et al., 1992), these correlations are likely due to aquifer processes (Andrews, 2006). In the MR-FC, the $\delta^{13} \mathrm{C}$ and $\delta^{18} \mathrm{O}$ values for Unit 4 are obviously higher relative to those of Units 1 and 2 , while the lowest $\delta^{13} \mathrm{C}$ and $\delta^{18} \mathrm{O}$ values showed a similar range among units (Fig. 10). Thus, it is likely that the $\delta^{13} \mathrm{C}$ and $\delta^{18} \mathrm{O}$ contents of the initial recharge waters were similar among all units, whereas isotopic evolution during infiltration from the soil zone to the discharge location differed (Fig. 10). According to this interpretation, climate conditions, vegetation type, and catchment area characteristics were similar throughout the deposition of the MR-FC (Darling, 2004). By contrast, groundwater residence time, upstream calcite precipitation, and topographic changes (from recharge to discharge areas) differed (Andrews, 2006).

\section{Depositional Model of the MR-FC}

Fossilized speleothems below the MR-FC clearly indicate that a stable cave environment existed before the deposition of the MR-FC (Hill and Forti, 1997). Interestingly, my petrographic and isotopic

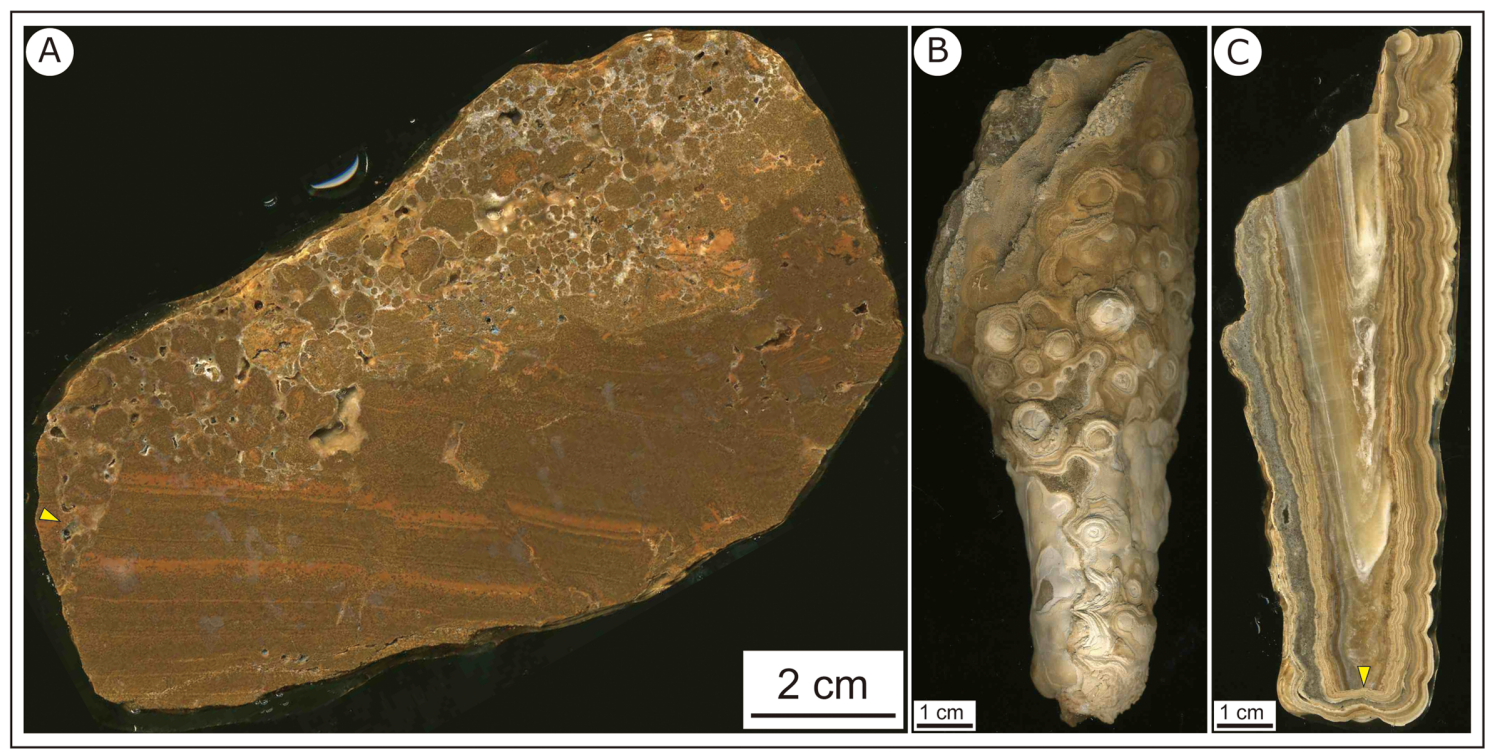

Figure 11. Petrographic features indicative of the formation process of the MR-FC. A) Red clay clasts overlie the laminated clays. The yellow arrow indicates an internal crack of laminated red clays. B-C) Sequence of change from a typical stalactite to biogenic micro-stromatolitic structures. The yellow arrow indicates the broken tip of a typical stalactite. 


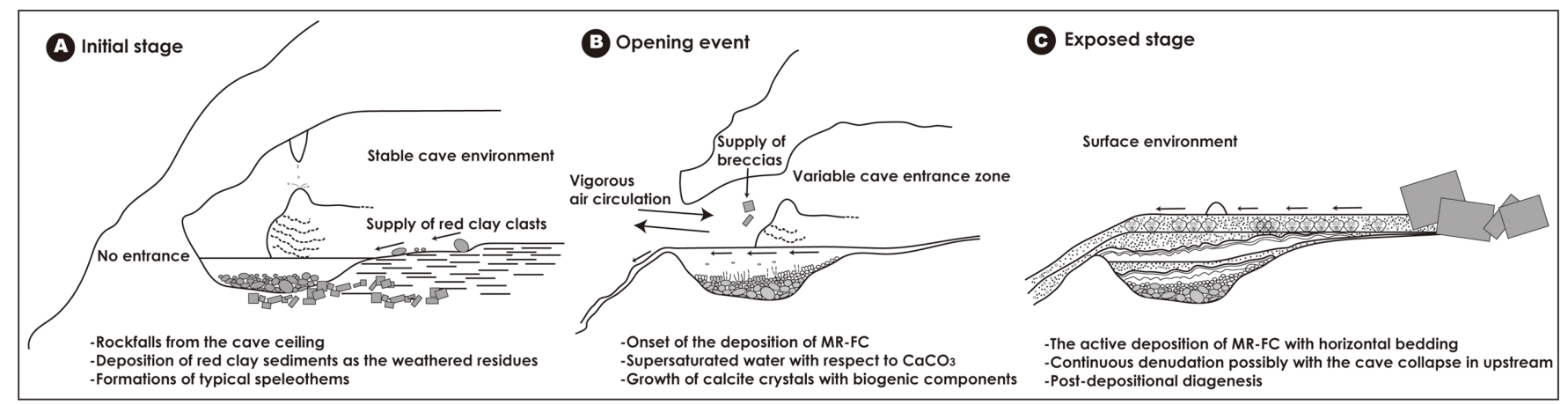

Figure 12. Schematic diagram of the formation of the MR-FC. A) A stable cave environment was present in the initial stage, i.e., before deposition of the MR-FC. B) The opening of the cave was closed by surface denudation. C) The dominant deposition mechanism for the MR-FC in the near-surface environment after further denudation and upstream cave collapse.

data indicate that the MR-FC has not deposited under low energy conditions of typical cave environment. Previous results for the MR-FC show that water supersaturated with calcium carbonate precipitated secondary mineral deposits both on and under the substrates (e.g., González et al., 1992; Jo et al., 2007). This differs from typical speleothems, where most dripstones grow when substrates have a relatively small amount of impurities. Although cave coralloids are largely similar to the branching crystalline layers of the MR-FC, active precipitation of calcite and aragonite in the subsurface, both during and after periods of extremely high supply of detrital particles, is not characteristic of speleothems (Hill and Forti, 1997). The predominance of microbial textures and organic fragments throughout the MR-FC does not accord with an oligotrophic cave environment (Jung and Jo, 2017). Most importantly, the colonies of photosynthetic organisms in the MR-FC clearly indicate that this freshwater carbonate was not deposited in a typical cave environment (Jung and Jo, 2017). Furthermore, the higher $\delta^{13} \mathrm{C}$ and $\delta^{18} \mathrm{O}$ contents of the MR-FC are compatible with an environment that was gradually exposed to the surface during the deposition process, where the parent groundwater of the upper units came into abrupt contact with the outside atmosphere (Fig. 12) (e.g., Šušteršič, 2007). In summary, our data suggest that the MR-FC was produced during the topographic evolution of a low-energy cave environment exposed by surface denudations and cave collapse events.

Based on our findings, we propose a conceptual model of the MRFC as follows: 1) during the initial stage, typical speleothems grew in a low-energy cave environment (the speleothem facies under the MRFC); 2) the cave entrance gradually opened through surface denudation (Units 1 and 2); and 3) tufa deposition subsequently occurred in accordance with a supply of biogenic components from the near-surface environment (Units 3 and 4) (Fig. 12). These stages are supported by the petrographic and isotopic data. The clastic bed of Unit 1 overlays typical cave sediments (laminated red clay) suggestive of relatively calm subaqueous conditions (i.e., a pond-like micro-topography) capable of capturing clay particles (Bosch and White, 2007). The crystalline bed of Unit 1, indicating kinetic fractionation of carbon and oxygen isotopes (unlike the case of Korean speleothems; e.g., Hendy, 1971; Andrews, 2006), suggests that a cave entrance allowed for evaporation and rapid $\mathrm{CO}_{2}$ degassing through vigorous air circulation. Andrews (2006) reported that the effects of evaporation on tufa $\mathrm{d}^{18} \mathrm{O}$ content are clear only in arid and semi-arid areas, especially in small and shallow stagnant pools (e.g., Liu et al., 2005). Above the clastic bed of Unit 2 of the MR-FC, changes in sediment components are obvious, indicating that the ratio of physical fragmentation to chemical weathering changed markedly (Bosch and White, 2007). Also, the slopes of the regression lines for ${ }^{13} \mathrm{C}$ and $\delta^{18} \mathrm{O}$ indicate a rapid $\mathrm{CO}_{2}$ degassing process. The subsequent surface denudation seen during the deposition of Units 3 and 4 could have allowed the sediment composition of Unit 2 to be largely retained, or to change only slightly toward a higher proportion of chemically weathered components (Šušteršič, 2007). The positive $\delta^{13} \mathrm{C}$ values for Unit 4 were likely due to a more rapid $\mathrm{CO}_{2}$ degassing process, poor vegetation cover, and a larger proportion of carbon isotopes contributed from upstream bedrock (Hendy, 1971; Andrews et al., 1997). The results of this study suggest that topographic evolution near the discharge location of the karst cave system was the most likely cause of the $\delta^{13} \mathrm{C}$ and $\delta^{18} \mathrm{O}$ profiles of the MR-FC.

\section{Conclusion}

Petrographic and isotopic data for the MR-FC in Jeongseon-gun, South Korea, indicate that this buried freshwater carbonate deposit formed near a cave entrance zone throughout the evolution of the local topography, which was probably characterized by surface denudation and upstream cave collapse. Thus, the MR-FC can be considered as a type of small-scale tufa succession, because most of it was affected by sunlight and it exhibits sedimentary textures differing from those of speleothems, as well as a variety of biogenic components. Previous studies reported that changes in topography and altitude during orogenic events can be determined by analysis of tufa deposits. This study demonstrates that carbonate sedimentary facies near a cave entrance zone provide evidence of topographic changes in the local environment. This study also provides an example of the separation of freshwater carbonates, i.e., of speleothem and tufa.

\section{Acknowledgments}

This research was supported by a National Research Foundation of Korea (NRF) grant funded by the Korean government (Ministry of Science and ICT) (NRF-2015R1A4A1041105, NRF-2016R1C1B2016525, 
and NRF-2019R1H1A1101097). This work was also partially supported by a Korea Basic Science Institute National Research Facilities \& Equipment Center grant funded by the Korean government (Ministry of Education) (2019R1A6C1010006).

\section{References}

Andrews, J.E., 2006, Palaeoclimatic records from stable isotopes in riverine tufas: Synthesis and review. Earth-Science Reviews, v. 75, pp. 85104.

Andrews, J.E., Riding, R., and Dennis, P.F., 1997, The stable isotope record of environmental and climatic signals in modern terrestrial microbial carbonates from Europe. Palaeogeography, Palaeoclimatology, Palaeoecology, v. 129, pp. 171-189.

Arenas, C., Gutiérrez, F., Osácar, C., and Sancho, C., 2000, Sedimentology and geochemistry of fluvio-lacustrine tufa deposits controlled by evaporite solution subsidence in the central Ebro Depression, NE Spain. Sedimentology, v. 47, pp. 883-909.

Bosch, R.F., and White, W.B., 2007, Lithofacies and transport of clastic sediments in karstic aquifers. In: Sasowsky, I.D., and Mylroie, J. (Eds.), Studies of Cave Sediments. Springer, Dordrecht, pp. 1-22.

Capezzuoli, E., Gandin, A., and Pedley, M., 2014, Decoding tufa and travertine (fresh water carbonates) in the sedimentary record: The state of the art. Sedimentology, v. 61, pp. 1-21.

Chafetz, H.S., and Folk, R.L., 1984, Travertines: depositional morphology and the bacterially constructed constituents. Journal of Sedimentary Petrology, v. 54, pp. 289-316.

Chough, S.K., 2013, Geology and sedimentology of the Korean Peninsula. Elsevier, Waltham, 35 p.

Darling, W.G., 2004, Hydrological factors in the interpretation of stable isotope proxy data present and past: a European perspective. Quaternary Science Reviews, v. 23, pp. 743-770.

Dandurand, J.L., Gout, R., Hoefs, J., Menschel, G., Schott, J., Usdowski, E., 1982, Kinetically controlled variations of major components and carbon and oxygen isotopes in a calcite-precipitating spring. Chemical Geology, v. 36, pp. 299-315.

Evans, J.E., 1999, Recognition and implications of Eocene tufas and travertines in the Chadron Formation, White River Group, Badlands of South Dakota. Sedimentology, v. 46, pp. 771-789.

Ford, T.D., and Pedley, H.M., 1996, A review of tufa and travertine deposits of the world. Earth-Science Reviews, v. 41, pp. 117-175.

González, L.A., Carpenter, S.J., and Lohmann, K.C., 1992, Inorganic calcite morphology: Roles of fluid chemistry and fluid flow. Journal of Sedimentary Petrology, v. 62, pp. 382-399.

Hill, C., and Forti, P., 1997, Cave minerals of the world. National Speleological Society, Huntsville, $45 \mathrm{p}$.

Hendy, C., 1971, The isotopic geochemistry of speleothems-I. The calculation of the effects of different modes of formation on the isotopic composition of speleothems and their applicability as palaeoclimatic indicators. Geochimica et Cosmochimica Acta, v. 35, pp. 801-824.

Jung, D.-Y., and Jo, K., 2017, Microbial structures and their distributions in cave tufa formations from a twilight zone of the Baeg-nyong Cave. Journal of the Geological Society of Korea, v. 53, pp. 743-758 (in Korean with English abstract).

Jo, K.N., Woo, K.S., and Lee, K.J., 2007, Texture and origin of the tufa in Moorungri, Jeongseon, Korea. Journal of the Geological Society of Korea. v. 43, pp. 395-413 (in Korean with English abstract).

Jo, K., Woo, K.S., Hong, G.H., Kim, S.H., and Suk, B.C., 2010, Rainfall and hydrological controls on speleothem geochemistry during climatic events (droughts and typhoons): An example from Seopdong Cave, Republic of Korea. Earth and Planetary Science Letters, v. 295, pp. $441-450$.

Jones, B., 2010, Microbes in caves: agents of calcite corrosion and precip- itation. In: Pedley, H.M., and Rogerson, M. (Eds.), Tufas and Speleothems: Unravelling the microbial and Physical Controls. Geological Society, London, pp. 7-30.

Kano, A., Matsuoka, J., Kojo, T., and Fujii, H., 2003, Origin of annual laminations in tufa deposits, southwest Japan. Palaeogeography, Palaeoclimatology, Palaeoecology, v. 191, pp. 243-262.

Knapp, E.P., Terry, D.O., Harbor, D.J., and Robert, C.T., 2007, Reading Virginia's paleoclimate from the geochemistry and sedimentology of clastic cave sediments. In: Sasowsky, I.D., and Mylroie, J. (Eds.), Studies of Cave Sediments. Springer, Dordrecht, pp. 95-106.

Korean Meteorological Administration, 2020, Homepage of Korean Meteorological Administration. http://www.kma.go.kr [accessed on 4th Feb. 2020].

Liu, Z., Li, Q., Sun, H., Wang, J., and Wu, K., 2005, Diurnal variations of hydrochemistry in a travertine-depositing stream at Baishutai, Yunnan, SW China: observations and explanations. In: Ozugul, M., Yagiz, S., and Jones, B. (Eds.), Proceedings of $1^{\text {st }}$ International Symposium on Travertine, Pamukkale University, pp. 169-185.

Lopez, B., Camoin, G., Özkul, M., Swennen, R., and Virgone, A., 2017, Sedimentology of coexisting travertine and tufa deposits in a mounded geothermal spring carbonate system, Obruktepe, Turkey. Sedimentology, v. 64, pp. 903-931.

Moore, G.W., 1952, Speleothem-a new cave term. National Speleological Society News, v. 10, pp. 2.

Pedley, H.M., Martin, J.A.G., Ordóñez Delgado, S., Garcia del Cura, M.A., 2003, Sedimentology of Quaternary perched springline and paludal tufas: criteria for recognition with examples from Guadalajara Province, Spain. Sedimentology, v. 50, pp. 23-44.

Pentecost, A., 2005, Travertine. Springer, Berlin, 11-18 p.

Romanek, C.S., Grossman, E.L., and Morse, J.W., 1992, Carbon isotope fractionation in synthetic aragonite and calcite: effects of temperature and precipitation rate. Geochimica et Cosmochimica Acta, v. 56, pp. 419-430.

Šušteršič, F., 2007, Cave sediments and denuded caverns in the Laški Ravnik, classical karst of Slovenia. In: Sasowsky, I.D., and Mylroie, J. (Eds.), Studies of Cave Sediments. Springer, Dordrecht, pp. 123-134.

Taborosi, D., 2006, Biologically influenced carbonate speleothems. Geological Society of America Special Paper, v. 404, pp. 307-317.

Usdowski, E., Hoefs, J., Menschel, G., 1979, Relationship between ${ }^{13} \mathrm{C}$ and ${ }^{18} \mathrm{O}$ fractionation and changes in major element composition in a recent calcite-depositing spring-a model of chemical variations with inorganic $\mathrm{CaCO}_{3}$ precipitation. Earth and Planetary Science Letters, v. 42, pp. 267-276.

White, W.B., 2007, Paleoclimate records from speleothems in limestone caves. In: Sasowsky, I.D., and Mylroie, J. (Eds.), Studies of Cave Sediments. Springer, Dordrecht, pp. 135-175.

Woo, K., 2001, Scientific investigation on Mt. Mindoong area. Jeongseongun, $17-188$ p (in Korean).

Yoon, K.H., 2007, Sedimentation and diagenesis of the Lower Paleozoic Daegi Formation. M.S. dissertation, Kangwon National University, 4$10 \mathrm{p}$ (in Korean).

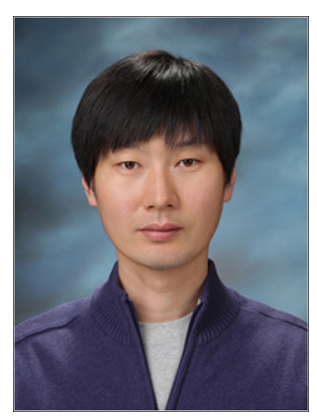

Kyoung-nam Jo is an assistant professor at the Department of Geology, Kangwon National University (KNU), Republic of Korea. He earned his M.S. degree from the Department of Geophysics, KNU and Ph.D from the Department of Geology, KNU. He was awarded the National Young Scientist of the Year from the Korean Academy of Science and Technology (KAST) in 2014 and the Young Geologist from the Geological Society of Korea in 2011. He has been studying on Quaternary paleoclimatology by focusing on natural carbonate materials from various terrestrial and marine sediments. 